\title{
TRAINING FOR SORGHUM FLOUR BASED CAKE MAKING AS A PART OF FAMILY WELFARE PROGRAM EMPOWERMENT IN PASIRMULYA BANDUNG
}

\author{
Farah Levyta $^{1 *}$, Dianka Wahyuningtias ${ }^{2}$, Sarim Sarim ${ }^{3}$ \\ Hotel Management Department, Faculty of Economic and Communications \\ Bina Nusantara University \\ farah.levyta@binus.edu
}

\begin{abstract}
Sorghum is a plant of a family of grasses and is still a family with rice, corn, and wheat. Sorghum grows a lot in the yard of Pasir Mulya residence house Banjaran District Bandung West Java. House wife in this village have not used much of this sorghum plant as food. The purpose of this training is to provide knowledge to the house wife about the benefits of sorghum as a cake-making material. The focus of this research is the process of empowering women through training and mentoring to good packaging, so that the house wife can have activities that produce and help the economy in the area. Data collection techniques used in this research are observation, interview and documentation. The data obtained were analyzed using data analysis technique. The results stated that the process of empowerment of house wife group through the training of cooking skills by way of prescribing, teaches the making of correct cookies and hygiene's, training the use of the right tools, the packaging process to produce a good product and worth selling. The results of sorghum-based cookies are expected to become a consumable gift from the Pasir Mulya.
\end{abstract}

Keywords: Training, cake, sorghum, empowering, community

\section{INTRODUCTION}

Sorghum is mostly grown by resource-limited farmers with minimal inputs which is one of the reasons for its low productivity. The yield and quality of sorghum produce is affected by a wide array of biotic (insect pests and diseases) and abiotic (drought and problematic soils) constraints. The important productivity-limiting constraints are: shoot fly (Atherigona soccata) (India and Eastern Africa), stem borer (Chilo partellus) (India and Africa), midge (Contarinia sorghicola) (Eastern Africa and Australia) and head bug (Calocoris angustatus) [India and Western and Central Africa (WCA)] among pests; grain mold (complex of fungi predominantly Fusarium spp, Curvularia spp, Aspergillus spp, Alternaria spp) (all regions) and anthracnose (Colletotrichum graminicola) (WCA and northern India) among diseases; Striga (Striga asiatica, S. densiflora, S. hermonthica) (all regions in Africa); drought (all regions); and problematic soils - saline (some parts of India and Middle East) and acidic (Latin America). (Belum VS Reddy*, 2004).

Sorghum grain endosperm texture is defined in terms of the proportion of corneous (horny/glassy/vitreous/steely) endosperm relative to floury (mealy/chalky/opaque) endosperm in the grain. Grains with a high proportion of corneous endosperm tend to be more resistant to breakage during decortication (dehulling) and milling than grains with a high proportion of floury endosperm. Resistance of the grain to breakage is often referred to as grain strength or hardness. Sorghum grain endosperm texture is of importance as "hard" grains tend to yield proportionally more clean (uncontaminated with bran) endosperm of large particle size during milling operations than "soft" grains. "Hard" grains are also more resistant to insect and mould damage than "soft" grains. (Taylor \& Taylor, 2008).

Other varieties of sorghum are also used for food in various parts of the world, including parts of Africa, Central and South America, China, and India. In Eastern and southern Africa, for example, traditional sorghum varieties of moderate tannin content are widely grown and used for staple food and alcoholic beverages. Their agronomic advantages outweigh any negatives such as reduced nutrient availability or astringency. In Southern Africa, small-scale farmers intercrop tannin and tannin-free 
sorghums in areas prone to high bird predation in order to reduce grain losses in the field (Awika \& Rooney, 2004)

In Wangun hamlet, sorghum is planted mostly in the garden or in the yard of the yard. Housewives in Wangun village, usually use sorghum as a snack. Sorghum seeds, usually fried then will change like corn flows. Popping corn is then sprinkled with salt so it tastes savory. At harvest time, sorghum is not used optimally, in fact this material has high nutritional value and economic value. With the existence of Sorghum (Sorghum bicolor L. Moench) is a plant of a family of grasses and is still a family with rice, corn, and wheat. Sorghum grows a lot in the yard of Pasir Mulya residence house Banjaran District Bandung West Java. Sorghum seeds can be used as a substitute for rice (corn cantel), popcorn and can also be crushed to make flour. Housewifes group in this village have not used much of this sorghum plant as food. The purpose of this training is to provide knowledge to them about the benefits of sorghum as a cake-making material. This activity requires training and mentoring from the beginning until the community can run her own business. The focus of this research is the process of empowering women through training and mentoring to good packaging, so that they can have activities that produce and help the economy in the area. Data collection techniques used in this research are observation, interview and documentation. The data obtained were analyzed using data analysis technique. The results stated that the process of empowerment of house wife group through the training of cooking skills by way of prescribing, teaches the making of correct cookies and hygiene's, training the use of the right tools, the packaging process to produce a good product and worth selling. The results of sorghum-based cookies are expected to become a consumable gift from the Pasir Mulya communities, this should be used to provide counseling, as well as awareness of mothers, that sorghum can be another food if processed in different ways.

Common problems that often occur in Wangun village for improvement and utilization and the economic value of sorghum are:

1. Residents of Wangun hamlet, especially PKK community, do not have expertise in making sorghum flour-based foods

2. How to provide training and assistance to PKK community to be able to make products properly and correctly.

3. How to make good packaging for food that has been made.

4. Providing the role of PKK community to be productive in their village

\section{The Purpose Of The Study}

1. PKK community has its own income and can develop according to new skills

2. Making new products from processed sorghum

\section{Research Methodology}

Development needs to be directed towards utilization the potential of local natural resources, increased productivity rural labor especially in strengthening resilience sustainable food and economic empowerment society. Increasing food security must be based on raising the "strength" of local resources and as small as possible depending on input from the outside (import). Regional development should be development from the community, by the community and for the community. From society means in producing value added development, must use resources (production factor) owned and or controlled by the community a lot (comparative advantage). By society means deep regional value added creation must be carried out immediately (active participation) many people are good individually or through economic organizations (small businesses, medium businesses, cooperative, big business). With from the community and by the community automatically added value development will be directly enjoyed by many people (for the community) that is through the factor share mechanism in the form of income from factors of production and functional income (income as an economic agent) (Marsigit, 2010). This type of cake is one of the products that is easy to sell. in addition to being able to sell their own products can be deposited to the shop. the expiration date of the cake is also quite long (Dr. Hernita \& Iwan Perwira, 2017)

The implementation of community service activities in Wangun Hamlet, PasirMulya village, sub-district, the implementation team shared activities in terms of training and mentoring for PKK 
community The approach taken in this PKM assistance is through participatory approach method. Which is divided into several stages, namely:

1. Survey and data collection and analysis of activities needed to find information about activities related to making sorghum flour-based cakes,

2. Trial of making cakes and foods that usually use wheat flour into sorghum flour.

3. Training on making sorghum flour based cakes, including

3.1 Discussion of the creation of sorghum flour-based food products

3.2 Training on the manufacture of making Sorghum flour-based foods including how to choose ingredients, read recipes, weigh ingredients, process of making and cooking

3.3 Assistance in the process of making food, presenting and packaging, monitoring activities, and coaching groups to monitor the continuity of food making business.

\section{Sorghum Flour Making Process}
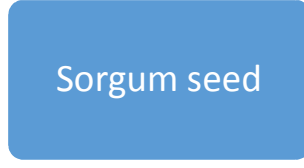

Sorgum Flour

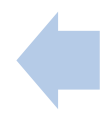

Making Flour

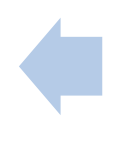

Cleaned

Sorgum

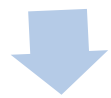

Soaking

Strain

The tools used in this study were Sorghum Flour, manual scales for cakes, hand mixers, baking pans, ovens, stainless basins, gas stoves, pancake molds from clay.

\section{RESULT AND DISCUSSION}

The implementation of community service activities through the development of processed sorghum flour products in the Wangun hamlet of PasirMulya village, with the main aim to increase the creativity of PKK Comunity Wangun village. The results of the implementation of partnership activities in Wangun Hamlet have been the introduction of knowledge and skills for the manufacture of sorghum flour processed products in Wangun hamlet to be developed into products such as pastries, cakes and traditional snacks. Constraints that often arise are very short product life, and utilization that is not optimal. Therefore, the thoughts and skills to utilize sorghum flour into processed products that are economically valuable, hygienic and of high and balanced nutritional quality are very important to be trained in the community. Sorghum flour processing can be done using simple technology that can easily be done by the community, is also an intermediate product that is very flexible to be processed into a variety of food products that are popular, especially pastries, pancakes and market snacks. In the form of processed, sorghum flour products will be favored by various layers of society including children and adolescents because in addition to their attractive appearance and flavor, these products are also healthier than other products that have been on the market.

In general, the problems are faced by the village community for increase consumption and economic value from local food ingredients are:

1. The community does not yet have skills in making flour with good quality.

2. The community does not yet have the equipment to make local flour.

3. The community does not understand the way processing food products made from local flour like wet noodles, noodles instant, crackers, peaches and biscuits.

4. The community does not understand how to market the product local processed food. (Muhtadi, Rauf, Harismah, \& Saifuddin, 2016)

In the partnership activities in the Wangun sub-village, training and mentoring for community 
included:

1. Discussion about the creation of sorghum flour-based food products

2 Training on making sorghum flour-based food making includes how to choose ingredients, read recipes, weigh ingredients, process of making and cooking

3 Assistance in the process of making food, presenting and packaging, monitoring activities, and coaching groups to monitor the continuity of food making business.

The benefits gained by the Wangun community are:

1. Increased knowledge and skills in processing sorghum flour into sorghum flour processed products in accordance with the skills and creativity of mothers.

2. Increased knowledge and skills to produce pastries, cakes and traditional snacks from sorghum flour

The implementation of the partnerships in the hamlet of Wangun certainly encounters obstacles and obstacles, namely the production and packaging technology for developing flour processed products, is still a reason for PKK community to start and develop a business based on sorghum flour processed products. Evaluation records of these constraints and constraints are certainly very valuable in following up on the implementation of community service activities in Wangun hamlet.

\section{CONCLUSION}

From the activities of the Partnership for the development of sorghum flour processed products in the hamlet of Wangun Pasir village, the following results have been obtained:

1. Increased knowledge and skills through training and mentoring activities for the manufacture of processed sorghum flour products such as pancakes, pastries and other traditional snacks for community

2. Increased knowledge and skills in diversification of sorghum flour processed products through training and mentoring activities for making pancakes, pastries and traditional snacks

3. The growth of the spirit of togetherness and sustainability of the program by involving the village government, related agencies and private parties in the Wangun hamlet of PasirMulya village greatly helped the development of sorghum flour-based products and the local economic potential in Wangun hamlet.

\section{Suggestion}

Based on the discussion and conclusions above, we present several suggestions, including: 1. Obstacles in the form of enthusiasm to initiate entrepreneurship are still very low, so that people need to be motivated and successful examples for the development of sorghum flour-based products

2. There needs to be support for advanced programs, to increase the enthusiasm, skills and marketing ability of the women members of the Wangun hamlet PKK

\section{REFERENCES}

Awika, J. M., \& Rooney, L. W. (2004). Sorghum phytochemicals and their potential impact on human health. Phytochemistry 65 (2004) 1199-1221, 1199-1221.

Belum VS Reddy*, S. R. (2004). Sorghum Research Reports. ISMN 45, 5.

Dr. Hernita, S. M., \& Iwan Perwira, S. M. (2017). Pengembangan Inovasi Kue Tradisional Putu Cangkir Dalam Penguatan Ekonomi Masyarakat Di Kabupaten Gowa. SINDHAR III (Seminar Ilmiah Nasional dan Diseminasi Hasil Riset), 83-90.

Marsigit, W. (2010). Development of Bengkulu Local Food Processing Products Diversity to Support Sustainable Food Security. AGRITECH, Vol. 30, No. 4, NOVEMBER 2010, 2565-264. 
Muhtadi, Rauf, R., Harismah, K., \& Saifuddin. (2016). PENGEMBANGAN PRODUK OLAHAN TEPUNG SAYURAN DI DESA SINDON. WARTA, Vol .19, No.1, Maret 2016: 83 - 89 ISSN 1410-9344, 83-89.

Sustainable Coffee Platform of Indonesia (SCOPI). (2016, April Thursday). https://www.globalcoffeeplatform.org. Diambil kembali dari https://www.globalcoffeeplatform.org: https://www.globalcoffeeplatform.org

Taylor, J. R., \& Taylor, J. (2008). Five Simple Methods for the Determination of. INTSORMIL Scientific Publications, 9.

www.globalcoffeeplatform.org. Report Activities SCAA Event 2016, Indonesia as Portrait Country 